\title{
Biotechnology Knowledge Transfer between the Hammer of Resources and the Oak of the Terrorist Threat
}

\author{
Shadia Omar \\ Queen's University Belfast, Ireland
}

\begin{abstract}
This paper proposes scientific and systematic analyses to the current problems that facing the transfer of the Biotechnology Knowledge in Sudan. Sudan is included in the terrorist countries and been suspected for long time for growing interest in Bio-weapons, therefore Sudan has been prevented from gaining the knowledge and means to develop biotechnology applications particularly in Biology and Nuclear Biotechnology. This prevention could not be announced or in written declarations because it will be against the Convention on Biological Diversity (CBD) and the Universal Declaration of Human Rights (UDHR) and it is worth to mention that USA has not signed the CBD. The paper studies other problems that have their impact on Biotechnology development in Sudan such as economic problems and government commitment towards research fund and developing manpower's skills. Sudan has a wide range of biodiversity which enables the country to enter the era of third generation biotechnology, however it failed to manage those resources because of the slow profit turnover and that the government has depended heavily on the oil industry. In general, the country lacks sustainable and basic laboratories with the essential skills and facilities for research and diagnosis. The research output has decreased dramatically, the libraries budget consisted entirely of salaries and wages and the research funding and academic staff are at very low level particularly among females. The dual use dilemma and the reasons of listing Sudan as Bio-threat have been explained in the paper. The paper also includes suggestion on how to improve and enable the environment for biodiversity conservation which would include the government political goodwill for the cause of biodiversity and to remove Sudan from the terrorist list, sufficient job opportunities and undertaking and considering financial resources and financial mechanisms.
\end{abstract}

\section{Definition of Biotechnology}

Biotechnology, being such an important area of study, attempts has been made to define it. It has been recognised that a complete definition of biotechnology is difficult due to such a wide range of its usage.

The United Nations Convention on Biological Diversity defines biotechnology as: (Any technological application that uses biological systems, living organisms, or derivatives thereof, to make or modify products or processes for specific use) (United Nation 1992). The broad definition of biotechnology is simply the industrial use of living organisms (or parts of living organisms) to produce foods, drugs, or other products (Nature Biotechnology 1999)

The oldest biotechnologies include fermentation and plant and animal hybridisation. The newest biotechnologies range from protein separation technologies to genomics and combinational chemistry.

A sampler of fields that fall under biotechnology's broad umbrella would include: Bacteriology, Biochemical engineering, Bioinformatics, Bioprocessing, Cell biology, Chromatography, Computational \& mathematical modeling, Developmental and molecular genetics, DNA technologies, Electrophoresis, Embryology, Immunology, Materials science, Microbiology, Nucleic acid chemistry, Protein engineering, and Virology (Nature Biotechnology 1999). 


\section{History of Biotechnology}

The origin of biotechnology can be traced back to prehistoric times, when microorganisms were already used for processes like fermentation. Although a molecular biologist may consider cloning of DNA to be the most important event in the history of biotechnology, the latter has actually been rediscovered in 1970's for the third time during the last century.

In 1920's Clostridium acetobutylicum was used by Chaim Weizmann for converting starch into butanol and acetone; the latter was an essential component of explosives during World War I. This raised hopes for commercial production of useful chemicals through biological processes, and may be considered as the first rediscovery of biotechnology in the past century. Similarly, during World War II (in 1940's), the production of penicillin (as an antibiotic discovered by Alexander Fleming in 1929) from cultures of Pencillium notatum, marked the second rediscovery of biotechnology. This was the beginning of an era of antibiotic research. The third rediscovery of biotechnology is its recent reincarnation in the form of recombinant DNA technology, which led to the development of a variety of gene technologies and is thus considered to be the greatest scientific evolution of last century. (www.molecular-plant-biotechnology.info)

Biotechnology, as word indicates, is the product of interaction between the science of biology and technology. This relationship between science and technology has been observed to be complex, so that not only has the science influenced technology, but also the technology has influenced the science. Because of this complex relationship and its major impact on human welfare, it is believed that biotechnology in future may become a major force for human existence.

Already, the products of biotechnology (including diagnosis, prevention and cure of diseases; new and cheaper chemical products e.g. pharmaceutical drugs, new food sources and devices for environment protection and energy conservation ...etc.) are playing a very important role in employment, productivity, trade, economies and the quality of human life throughout the world.

\subsection{The rights for free knowledge and knowledge transfer}

The right for education, training and knowledge transfer is permitted and considered to be one of the human rights as long as it serves the development of oneself, community and nations within legal procedures and should not perform any act aimed at the destruction or threatening other countries. The Universal Declaration of Human Rights (UDHR) states:

Article 26

1. Everyone has the right to education. Education shall be free, at least in the elementary and fundamental stages. Elementary education shall be compulsory. Technical and professional education shall be made generally available and higher education shall be equally accessible to all on the basis of merit.

2. Education shall be directed to the full development of the human personality and to the strengthening of respect for human rights and fundamental freedoms. It shall promote understanding, tolerance and friendship among all nations, racial or religious groups, and shall further the activities of the United Nations for the maintenance of peace. 


\section{Article 29}

1. Everyone has duties to the community in which alone the free and full development of his personality is possible.

2. In the exercise of his rights and freedoms, everyone shall be subject only to such limitations as are determined by law solely for the purpose of securing due recognition and respect for the rights and freedoms of others and of meeting the just requirements of morality, public order and the general welfare in a democratic society.

These rights and freedoms may in no case be exercised contrary to the purposes and principles of the United Nations.

We also find the same rights stated in UNESCO Convention against discrimination in education. Article 1 state:

For the purpose of this Convention, the term 'discrimination' includes any distinction, exclusion, limitation or preference which, being based on race, colour, sex, language, religion, political or other opinion, national or social origin, economic condition or birth, has the purpose or effect of nullifying or impairing equality of treatment in education and in particular:

1. of depriving any person or group of persons of access to education of any type or at any level;

2. of limiting any person or group of persons to education of an inferior standard; subject to the provisions of article 2 of this Convention, of establishing or

3. maintaining separate educational systems or institutions for persons or groups of persons; or

4. of inflicting on any person or group of persons conditions which are incompatible with the dignity of man.

For the purposes of this Convention, the term 'education' refers to all types and levels of education, and includes access to education, the standard and quality of education, and the conditions under which it is given.'

\section{The Convention on Biological Diversity (CBD)}

The Convention on Biological Diversity (CBD), signed at the United Nations Conference on Environment and Development (UNCED) in 1992, was the first international environmental convention to develop measures for the use and protection of traditional knowledge, related to the biotechnology. Significant provisions include:

\section{Article 8. In-situ Conservation}

Each Contracting Party shall, as far as possible and as appropriate:

(j) Subject to its national legislation, respect, preserve and maintain knowledge, innovations and practices of indigenous and local communities embodying traditional lifestyles relevant for the conservation and sustainable use of biological diversity and promote their wider application with the approval and involvement of the holders of such knowledge, innovations and practices and encourage the equitable sharing of the benefits arising from the utilization of such knowledge, innovations and practices 
Article 10. Sustainable Use of Components of Biological Diversity

Each Contracting Party shall, as far as possible and as appropriate:

(c) Protect and encourage customary use of biological resources in accordance with traditional cultural practices that are compatible with conservation or sustainable use requirements The interpretation of these provisions has been elaborated through decisions by the parties (ratifies of the Convention). The parties to the Convention set a 2010 target to negotiate an international legally-binding regime on access and benefit sharing (ABS) at the Eighth meeting (COP8), 20-31 March 2006 in Curitiba, Brazil. The ABS negotiations addressed inter-governmental obligations related to genetic resources, and these involved measures related to the rights of indigenous and local communities to control access to and derive benefits from the use of genetic resources and associated traditional knowledge.

\subsection{Recourses and their impact on biotechnology development in Sudan}

The level of biotechnology research in Sudan is at a fairly low level. This is largely because of lack of infrastructure, skilled manpower and lack of commitment by the national government.

In recent years, biotechnology has been considered as an essential tool for socio-economic development by an increasing number of developing countries.

Yet, if anything, as the science frontier of the technology is advancing at an ever accelerating pace, commercial entry into modern biotechnology for most developing countries is rapidly moving away.

Globally, biotechnology science has been profoundly influenced by two factors, namely, the drastic reduction of public funds for research and the dominant role of the private sector in biotechnology R\&D for health care, agrifood and other industrial applications. The combined effect of these factors has been that technological advancement has remained stagnant in those areas that have been deemed unattractive in terms of returns on investment. These are precisely those areas that are of prime importance for Sudan (e.g. orphan crop and infectious disease research) in which biotechnology can have a profound effect.

Despite this, donor and technical support agencies have been reluctant to redirect part of their investments away from other conventional types of technology assistance towards biotechnology. The reason that is often invoked is the lack of an enabling environment in most developing countries which would translate biotechnology R\&D or import products and services into communitylevel benefits (World Bank).

At present it is very difficult to identify opportunities for new second generation biotechnological products since the Chinese, Indians and other such countries are producing these products at much lower costs. In this regard not only us, but USA and EU are also struggling to compete and indeed these economies have lost fermentation capacity for two decades (ISESCO).

It is, however, also certain that competitiveness in Biotechnology Industry will depend on the ability of application of third generation biotechnology. Sudan has a wide range of biodiversity which enables the country to enter the era of third generation biotechnology. 


\subsection{Biodiversity of microbes and food biotechnology}

Dirar (1997) noted that Sudan has over 80 indigenous fermented foods and beverages that are distinctly different from each other. This indicates an extensive variety and biodivesity in the microflora of the country. For example, "kisra", a food of the majority of Sudanese people, was studied by many workers (Mohamed et al. 1991; Hamad et al. 1992; El Khalifa and El Tinay, 1993, Hamad et al. 1997, Farahat, 1998). In spontaneous sorghum fermentation, Mohamed (1991) isolated seven species of bacteria, two species of yeast and four species of moulds

\subsection{Biodiversity of industrial microbes and biotechnology applications in Sudan}

Hamad (1986) isolated 29 different yeast species from samples taken from 9 locations in the Sudan. Some species were represented by up to 7 different strains (Baerwald and Hamad, 1984). Some yeast strains were described as thermo at $50 \mathrm{C}$ and osmotolerant in $60 \%$ sugar. Others have the ability to metabolise complex carbohydrates such as starch and inulin, and to produce alcohol. One of this yeast was tested for the production of single cell protein (SCP) and ethanol from molasses.

\subsection{Biodiversity and biotechnology applications in livestock}

\section{A) Artificial insemination}

The use of artificial insemination biotechnology for the development of livestock breeds in Sudan had been adopted since 1977 when the first centre was established to disseminate this technology. A few state centres are currently providing such a service (e.g. Gezira, Darfur). This technology is mainly used for the development of cattle livestock only, as it has not yet been successfully applied in camels (Musa et al. 1988).

\section{B) Vaccination}

To produce the rinderpest vaccine, scientists at the Animal Resources Research Corporation (ARRC) had already exploited a Iow-level biotechnology for the development of vaccine production and vaccination of animals in Sudan.

\subsection{Biodiversity and biotechnology application in human health}

Several studies had already used advanced level of biotechnology including DNA techniques and the use of monoclonal antibodies (MCAB) for the diagnosis of diseases like leishmaniasis, bilharzia, malaria, onchocercosis, mycetoma, and cancer.

Sudan has failed to manage these resources because of the slow profit turnover and the investors turning away. Oil has recently become an important trading resource; however, the management of this extremely beneficial resource is still under dispute, as is the distribution of the new-found wealth resulting from it (Salman, S.A et al 2003). This reflects on the government commitment towards the investment in biotechnology industry and research.

According to an estimate in 2005 Sudan's gross domestic product (GDP) is approximately 85 billion (CIA World Factbook) The investment gross fixed is $19 \%$ of the GDP and the industrial areas are oil, cotton ginning, textiles, cement, edible oils, sugar, soap distilling, shoes, 
petoleum refining, pharmaceutical, armaments, automobile/light truck assembly (CIA World Factbook).

As for research and publishing, the politicisation of higher education has relegated research to a secondary requirement for promotion purposes. Research budgets have practically disappeared from university budgets during the past decade.

Out of a total of 3,339 publications for the Sudan during the 27-year period 1973-99, Sudanese universities share is about $76.3 \%$. However, research output during the 1990 s decreased by about $22 \%$ from its level in the 1980 s for the country; University of Khartoum saw a $30 \%$ decline.

In 1994-95, the approved budget for 26 universities was about $\$ 9$ million. During the period 1989-90 to 1994-95, the approved development budget fluctuated between $6 \%$ and $18.5 \%$ of the proposed budget. The libraries' budget during 1992-98 consisted entirely of salaries and wages. Furthermore, subscriptions for periodicals declined in 1987 and subsequently discontinued in 1993 (www.bc.edu/bc_org/avp/soe/cihe/inhea/profiles/Sudan.htm).

\section{Table 1 Selected science and technology infrastructure}

\begin{tabular}{|c|c|c|}
\hline NAME OF INSTITUTION & NAME OF INSTITUTION & NAME OF INSTITUTION \\
\hline $\begin{array}{l}\text { Educational Institutions*: } \\
\text { University of Khartoum } \\
\text { Azhari University } \\
\text { University of Bakht Alruda } \\
\text { Sudan University of Science } \\
\text { and Technology } \\
\text { University of Sinnar } \\
\text { University of Gezirah } \\
\text { University of Juba }\end{array}$ & $\begin{array}{l}\text { University of Upper Nile } \\
\text { University of Kassala } \\
\text { Islamic University } \\
\text { University of Dongola } \\
\text { University of Zalengi } \\
\text { University of Al-Fashir } \\
\text { University Gedarif } \\
\text { University of Kordofan } \\
\text { Bayan College for S\&T }\end{array}$ & $\begin{array}{l}\text { Centres of R\&D and S\&T Service }{ }^{* *} \text { : } \\
\text { 1. Agricultural Research } \\
\text { Corporation } \\
\text { 2. Animal Resources Research } \\
\text { Corporation } \\
\text { 3. The Energy Research Institute } \\
\text { 4. The National Centre for } \\
\text { Research } \\
\text { 5. Economic \& Social research } \\
\text { 6. Renewable Research Institute }\end{array}$ \\
\hline
\end{tabular}

*Source: ASTI Country Profile - Sudan, January 2005** Source: Ministry of S\&T Website

Table 2 Number of academic staff in selected institutions in Sudan according to academic degree 2000/2001

\begin{tabular}{|c|c|c|c|c|c|c|c|c|}
\hline & \multicolumn{2}{|c|}{$\begin{array}{c}\text { Sudan university } \\
\text { of S\& T }\end{array}$} & \multicolumn{2}{|c|}{ Aviation Science } & \multicolumn{2}{|c|}{ Bayan S \& T college } & \multicolumn{2}{|c|}{$\begin{array}{c}\text { Science } \\
\text { and Technology }\end{array}$} \\
\hline & $M$ & $\mathbf{F}$ & $M$ & $\mathbf{F}$ & $M$ & $\mathbf{F}$ & $M$ & $\mathbf{F}$ \\
\hline PhD & 103 & 6 & 3 & 0 & 6 & 0 & 53 & 8 \\
\hline Master & 116 & 10 & 9 & 0 & 9 & 3 & 60 & 43 \\
\hline $\begin{array}{l}\text { High } \\
\text { Diploma }\end{array}$ & 31 & 9 & 2 & 0 & 0 & 0 & 2 & 0 \\
\hline Total & 250 & 25 & 14 & 0 & 15 & 3 & 115 & 51 \\
\hline
\end{tabular}

Source: CRHE Statistics \& Data Centre 
Table 3 Research Funding - Sudan 1999 to 2004

\begin{tabular}{|l|c|c|c|c|c|}
\hline \multicolumn{3}{|c|}{$\begin{array}{c}\text { Total gross domestic } \\
\text { expenditure on R\&D (GERD) }\end{array}$} & \multicolumn{3}{c|}{$\begin{array}{c}\text { GERD by sector of } \\
\text { performance (\%) }\end{array}$} \\
\hline & $\begin{array}{c}\text { Expenditure } \\
\text { (Sudanese } \\
\text { dinar) }\end{array}$ & \% GDP & Business & Government & $\begin{array}{c}\text { Higher } \\
\text { Education }\end{array}$ \\
\hline 1999 & 14300000 & 0.53 & $31.50 \%$ & $38.50 \%$ & $30.10 \%$ \\
\hline 2000 & 14900000 & 0.48 & $31.50 \%$ & $38.90 \%$ & $29.50 \%$ \\
\hline 2001 & 15240000 & 0.43 & $31.50 \%$ & $39.30 \%$ & $29.20 \%$ \\
\hline 2002 & 15400000 & 0.38 & $31.80 \%$ & $39.00 \%$ & $29.20 \%$ \\
\hline 2003 & 15650000 & 0.43 & $31.90 \%$ & $39.00 \%$ & $29.10 \%$ \\
\hline 2004 & 16373000 & $\ldots .$. & $33.60 \%$ & $38.30 \%$ & $28.10 \%$ \\
\hline
\end{tabular}

Source: UNESCO S\&T Indicators

\section{The Dual Use Dilemma}

The regulation of dual use biotechnology research is a highly contentious technical, political and societal issue. In the language of arms control and disarmament, dual use refers to technologies intended for civilian application that can also be used for military purposes. Many of the same methods for developing attenuated live vaccines against viral diseases can have offensive applications as well ( CB Weapons Today, V. II).

In discussing modifications of microorganisms that might have significance for bioweapons, Nixdorff and Bender identified four classes of microbial manipulations that have been the subject of intense debate within and outside the scientific community:

1. The transfer of antibiotic resistance to microorganisms,

2. Modification of the antigenic properties of microorganisms,

3. Modification of the stability of microorganisms in the environment, and

4. The transfer of pathogenic properties to microorganisms.

The National Institute of Health's (NIH's) recently-released research priorities for countering bioterrorism identified several categories of research activities in immunology and genomics that would be considered "provocative" if conducted by a hostile or rogue government. These include efforts to "identify pathogen-induced immunoregulatory and immunosuppressive effects" as well as to "analyse gene expression of agents of bioterrorism"( Fauci, A 2002).

\subsection{Bio-threat}

In the fall of 2001, letters sent through the U.S. mail containing powdered anthrax bacterial spores killed five people, infected 18 others, disrupted the operations of all three branches of the U.S. government, forced tens of thousands to take prophylactic antibiotics, and frightened millions of Americans. This incident demonstrated the deadly potential of bioterrorism and raised serious concerns about USA ability to defend itself against more extensive attacks. 
The interest of terrorist groups in biological weapons is no surprise. Biological weapons have a number of very attractive features for terrorist uses. Their killing power can approach that of nuclear weapons. They are relatively inexpensive to make. A small-scale biological weapon attack using a common disease organism, such as tularemia or plague, can be masked as a natural outbreak. The effects of a biological weapon attack are not apparent for several days, allowing the perpetrator time to vanish. The raw material - disease-producing strains of microorganisms - is fairly easy to obtain. In addition, the techniques and equipment that are used in ordinary biotechnology research and production can be used for biological weapons. While someone with a strong background in microbiology could certainly produce a crude biological weapon to affect a small number of people and create panic, sophisticated weapons require sophisticated knowledge. For terrorist groups, the most likely source of such knowledge would be state-sponsored biological weapons programmes, which have the financial and scientific wherewithal to perfect production and deployment techniques, and the organisms can be obtained from natural reservoirs (such as soil or animals), from culture libraries that provide such organisms for research purposes, or by stealing cultures from legitimate laboratories. There are other types of biological weapons proliferation that are of greater concern. The first involves experienced scientists traveling or moving abroad. A second type of proliferation involves scientists from other countries being brought to the proliferating country for training in biotechnology, microbiology, and genetic engineering techniques. A third form of proliferation involves private companies selling scientific expertise. A fourth type of proliferation occurs when the proliferating country sells equipment that can be used in biological weapons production. Such equipment is generally termed "dual-use", as it can be used for legitimate biotechnology production and for biological weapons production. The fifth kind of proliferation consists of published scientific literature. Just by reading scientific literature published in Russia in the last few years, a biological weapons developer could learn techniques to genetically engineer vaccinia virus and then transfer the results to smallpox; to create antibiotic-resistant strains of anthrax, plague, and glanders, and to mass-produce the Marburg and Machupo viruses. Billions of dollars that the Soviet Union and Russia put into biotechnology research are available to anyone for the cost of a translator.

\subsection{USA considers Sudan as Bio-threat}

USA suspects Sudan has aspired to develop a chemical warfare capability since the 1980s and received technical assistance from Iraq. Allegations of CW activities in Sudan were not confirmed. Sudan is a party to the CWC, but has only declared the possession of riot control agents. USA considers Sudan to be interested in a BW program as well ( Unclassified Report to Congress 2002).

On the $20^{\text {th }}$ of August 1998, U.S. Tomahawk cruise missiles struck and destroyed al-Shifa Pharmaceutical Factory in Khartoum. The United States said the attack was in response to the bombings two weeks earlier of U.S. embassies in Kenya and Tanzania, which it believed were orchestrated by Osama bin Laden. U.S. officials said the bombing of the Sudanese facility was necessary to prevent bin Laden from acquiring deadly nerve gas precursors that were being produced at al-Shifa.

The United States and Sudan in mid 2000 entered into a dialogue to discuss US counterterrorism concerns. By the end of the year Sudan had signed all 12 international conventions for combating terrorism. But Khartoum still had not complied fully with UN Security Council 
Resolutions 1044, 1054, and 1070, passed in 1996, which demand that Sudan ends all support to terrorists

Even though, there has been little evidence to indicate that Sudan has produced or transferred CBW material, technology or know-how to such terrorist organisations, the possibility has not been ruled out.

\subsection{Academic Freedom and Freedom of Association}

For all intent and purpose, academic freedom does not exist in Sudan and any attempt to defend such ideas could be construed as heresy or political disobedience. The continuous ideological repression and intellectual terrorism practised by Sudan government, lead to a dangerous form of mix between religion and scholarship, and the atmosphere necessary for free thinking became a piece of the past. The subject of academic freedom in Sudan was extensively covered by human rights organisations such as Amnesty International, Africa Watch, Article 19, Fund for Peace, and World University Service.

\section{Conclusions}

It is becoming increasingly evident that conventional program addressing health care and agricultural productivity needs in the developing world are becoming dependent on biotechnology to enhance their delivery prospects and benefit impacts. Clearly, in Sudan, biotechnology R\&D is not the be all and end all. It needs to be coupled with actions to strengthen adoptive capacity (i.e., introduction of information and other key technologies) and to introduce policy and institutional reforms, conducive to public and private investment.

The reason for this is that the ability of Sudan to use biotechnology for public good depends primarily on the capacity to absorb and adapt proprietary technology to its specific needs. Policies with regard to intellectual property protection, increasing scope for intervention, and biosafety are essential in generating an enabling environment for the application of biotechnology.

The government should create an enabling environment for biodiversity conservation by:

- Promoting political goodwill for the cause of biodiversity.

- Strengthening the institutional technical capacity by improving the technical infrastructure and strengthening the manpower base through training to carry out the tasks.

- Undertaking and considering financial resources and financial mechanisms as stated in articles 20 and 21 of the CBD.

Biotechnology is a multidisciplinary science and therefore, any Biotechnologist apart from having a good basic knowledge of basic molecular biology, requires knowledge in bioinformatics, information technology, engineering, statistics, genetic epidemiology, business management, product development and legal issues. It is true that no one person is likely to be an expert in all these fields, therefore specialists with the expertise above are to be required.

At present, there is an alarming shortage of manpower that is trained in biotechnology.

It is very important that immediate steps should be taken to overcome this vacuum. This can be achieved in the following ways: 
- Career opportunities should be established. There should be sufficient job opportunities with comparative remuneration packages to attract the top of the trade peoples and students.

- Fast-tracking for the needed human resources. An active international recruitment programme aimed at first to expatriates living abroad for transfer of technology and secondly offering job opportunities to retired scientists living abroad.

Biotechnological innovations or techniques developed for animals can also be applied to human health and even to agriculture or other industrial sectors. Thereby implying that biotechnology is Cross-Cutting Technology. Thus the management of economic benefits can be arranged in such a way as to take advantage of this cross-fertilisation characteristics of biotechnology.

Clearly as USA suspect and consider Sudan as Bio-threat this resulted on declining Sudanese applications for training courses and advanced courses in Molecular biology and biotechnologies abroad particularly in Europe and USA as well as the funds for research projects particularly if it involves developing Biotechnologies that considered as terrorist threat To eliminate this problems Sudan's government should take the necessary steps to withdraw Sudan from the BioThreat countries list.

\section{References}

The convention on Biological Diversity United Nation 1992. Retrieved on February 6, 2008. Source: Nature Biotechnology 1999 Media Kit. www.molecular-plant-biotechnology.info.

World bank.

Strategy for the development of Biotechnology in the Islamic world. ISESCO.

Salman, S.A., Al-Dasees, I.S., Ibrahim, A.G., El-Haj, A.Q.M., Al-Araki, M.A., Bashir, A.-T.A., Ghafour, H.A et al. (2003, December 03). Country Case Study-Sudan: Sudanese Experience in the Development and Evaluation of the Basic Education Curriculums, p.3.

Association for the Development of Education in Africa. Grand Baie, Maurice.

CIA The World Factbook (n.d.). Retrieved May 25, 2006 from: http://www.odci.gov/cia/publications/factbook/ geos/su.html

CIA The World Factbook (n.d.). Retrieved March 18, 2005 from: http://www.odci.gov/cia/publications/factbook/ geos/su.html, http://www.bc.edu/bc_org/avp/soe/cihe/inhea/profiles/Sudan.htm

For a description of national chemical and biological weapons programs prior to 1970, see SIPRI. 1973. The Problem of Chemical and Biological Warfare," CB Weapons Today, V. II (New York: Humanities).

Fauci, A. "Defining 'Sensitive' Information in the Life Sciences," oral presentation to the committee, September 9, 2002.

Unclassified Report to Congress on the Acquisition of Technology Relating to Weapons of Mass Destruction and Advanced Conventional Munitions 1 July Through 31 December 2002.

\section{Notes}

The Bioterrorism Response Act also establishes a national database to collect registration information including the names and locations of registered facilities; the listed biological agents and toxins they possess, use or transfer; and characterization and source data for listed agents they possess. The purpose of this database is to assist public health and law enforcement officials to identify the origin or source of a listed agent used to cause harm to the public. 